\title{
Pakistani Immigrant Organizational Spaces in Toronto and New York City
}

\author{
This article was published in 2016 in a Special Issue of the \\ Journal of Ethnic and Migration Studies
}

Migrant Cities: Place, Power, and Voice in the Era of Super-Diversity

To Cite: Chaudhary, Ali. R. and Luis Eduardo Guarnizo. 2016. "Pakistani Immigrant Organisational Spaces in Toronto and New York City" in Journal of Ethnic and Migration Studies. Special Issue: Migrant Cities: Place, Power and Voice in the Era of Super-Diversity. 42(6): 1013-1035 DOI: DOI:10.1080/1369183X.2015.1126084.

http://www.tandfonline.com/doi/full/10.1080/1369183X.2015.1126084\#.VuEr9ZOLT_Q 


\section{Pakistani Immigrant Organizational Spaces in Toronto and New York City}

Abstract

This study examines how multilayered 'contexts of reception' in two global migrant cities shape the size, programmatic domain and geographic scope of action of non-profit organizations serving the Pakistani immigrant communities in Toronto and New York City. Existing literature tends to overemphasize the role of state policies in determining the prevalence of immigrant organizations. Previous research is also divided into two epistemic camps, one focusing on locally-oriented organizations promoting settlement/incorporation and the other on transnational organizations - thus obscuring the relationships between these organizations. The present study addresses these limitations by examining how the combined effect of state policies, socioeconomic incorporation, community characteristics and societal attitudes shape the composition and geographical orientation of an immigrant group's collective organizational space. The study draws on a newly constructed database of Pakistani non-profit organizations based in Toronto and NYC and on qualitative research conducted in both cities. Contrary to our expectations and previous research, we found that it is not the state-sponsored multiculturalism in Toronto, but rather the affluence of the Pakistani community in NYC that is associated with the larger and more transnational of the two Pakistani organizational spaces. Findings also reveal tensions between local and transnationally-oriented organizations in both cities, reflecting growing fragmentation between affluent cosmopolitan immigrant elites and the impoverished segments of Toronto and NYC Pakistani communities.

Keywords: Immigration Organizations; Non-Profit Organizations; Contexts of Reception; Institutional Completeness; Pakistani Immigrants; Transnational Organizations; Toronto; New York City. 


\section{INTRODUCTION}

International migration continues to transform the social, economic and political landscapes of major metropolitan areas throughout the world (Foner et al. 2014). A growing body of scholarship examines how non-profit organizations located in receiving cities facilitate immigrant incorporation and cross-border transnational engagement between migrants' places of origin and settlement. Migrant organizations promote incorporation by providing access to social services, political engagement, and religious incorporation (Bloemraad 2006, 2005; Breton 2012, 2005; Cordero-Guzman 2005; De Graauw 2008; Levitt 2007; Min 2010; Moya 2005). They also foster and sustain transnationalism by facilitating migrants' economic, political and sociocultural engagement with their homelands (Lacroix 2011; Landoldt and Goldring 2010; Portes, Escobar and Radford 2007; Smith 2006). ${ }^{1}$

Existing literature largely focuses on how contextual conditions in receiving societies explain variation in the prevalence and development of migrant organizational infrastructures. However, previous research overemphasizes the centrality of state policies at the expense of other contextual factors. Existing research is also split into two, apparently unrelated, epistemic and empirical camps: one focused on immigrant organizations' role in processes of settlement and incorporation and the other on their role as transnational actors and agents of development in migrants' homelands. ${ }^{2}$ This analytic separation between local and transnationally-oriented

\footnotetext{
${ }^{1}$ This study uses the term non-profit organizations to refer to different types of immigrant organizations. While not all immigrant organizations have an official non-profit status, those used in this study are all registered non-profits.

${ }^{2}$ The terms immigrant and migrant are used interchangeably throughout the paper.
} 
immigrant organizations makes it difficult to uncover the dynamics and relationships between organizations with divergent geographic scopes of action.

In order to gain a better understanding of the contextual factors that shape immigrant groups' organizational infrastructure, research must move beyond state-centered analyses and overcome the epistemic division between local and transnational organizations. After all, immigrant organizations, whether working locally or transnationally and regardless of their domain of activity, are embedded in the same context of reception, belong to the same immigrant community, and thus form and occupy a collective social space. Using the case of Pakistani migrants, this paper analyzes how multilayered 'contexts of reception' including state policies, levels of socioeconomic incorporation, co-ethnic community characteristics, and the receiving society's attitudes towards Pakistani immigrants shape the size, programmatic focus, and geographic scope of the collective Pakistani immigrant organizational space (IOS) serving the Pakistani migrant communities in Toronto and New York City (NYC).

Data come from an original database covering the universe of Pakistani non-profit organizations in Toronto and NYC and from an analysis of data gleaned from 84 in-depth interviews with organization leaders, government officials and key informants. ${ }^{3}$ Findings reveal significant differences in the size, heterogeneity or degree of institutional completeness, and geographic scope of Pakistani organizational spaces in Toronto and NYC. However, variations in the two IOSs are not explained by differences in state-centered factors such as immigrant

\footnotetext{
${ }^{3}$ The data for this article come from a larger doctoral dissertation project carried out by the first author investigating the Pakistani immigrant non-profit sector in London, Toronto and NYC (Chaudhary 2015b).
} 
incorporation policies and national membership ideologies. Rather, varying levels of socioeconomic attainment in the Pakistani immigrant communities across the two cities, coupled with each community's internal composition, seem to better explain these variations. The only common phenomena found in both cities are significant local tensions between the leadership of the locally-focused settlement and incorporation organizations and the transnationally-oriented organizations focusing on Pakistan.

\section{BACKGROUND}

A well-established body of sociological research has demonstrated that not-for-profit organizations work as key meso-structural agents connecting individual citizens to larger sociopolitical and economic structures (Bloemraad 2006; Breton 2005, 1964; Marwell 2004). In addition, a growing literature within the field of international migration documents how contextual factors affect organizations facilitating migrants' settlement, integration, and transnationalism. However, most existing research concentrates on a particular subset of organizations, thus creating an epistemic bi-polarity where studies focus either on locallyoriented organizations associated with settlement and incorporation or transnational organizations facilitating engagement with migrants' places of origin (for an exception, see Gleeson \& Bloemraad 2012). This epistemic fragmentation obscures the shared contextual environment inhabited by both locally and transnationally oriented organizations. In addition, the concomitant empirical fragmentation makes it difficult to analyze the complete composition of a given migrant group's organizational infrastructure or relations between local and transnationally-oriented organizations. The present study moves beyond this fragmentation by 
comparing the entire Pakistani IOS in each of the cities under study. By analyzing all Pakistani migrant organizations, irrespective of their local or transnational orientation, we are able to analyze the overall geographic scope of the Pakistani immigrant organizational infrastructure and better understand the dynamics between local and transnational migrant organizations.

\section{Immigrant Organizational Space}

In order to analyze how a context shapes the complete organizational infrastructure serving the Pakistani immigrant communities in Toronto and NYC, this paper employs the concept of an immigrant organizational space (IOS). The concept of 'organizational space' builds on research examining organizational fields (DiMaggio and Powell 1983; Powell and DiMaggio 1991) and transnational social spaces (Faist 2000). ${ }^{4}$ It constitutes a heuristic tool to analyze the ecological environment in which organizations serving or representing an immigrant community are embedded. Analytically, IOSs encompass the dynamic set of relationships structuring the size (number of organizations), programmatic domain of action (social, economic, cultural, political, or religious), and geographic scope (local or transnational) of non-profit immigrant organizations. IOSs should not be equated with the geographic spaces in which they are located, for they are formed by a diverse array of organizations engaged at different scales (local, national, and international). Yet, for the present analysis, the boundaries of Pakistani

\footnotetext{
4 The concept of 'organizational field' within organization studies is primarily concerned with the micro-level interactions and patterns of domination and coalition among a group of organizations whose institutionally defined behaviors draw the boundaries of their organizational field of action (Bourdieu 1992; Vaughn 2008). Similarly, the concept of 'transnational social space' seeks to identify the actors in a given place who engage in transnational behaviors that ultimately generate a space of action that lies between an immigrant community's country of origin and country of settlement. In contrast, our use of the concept 'organizational space' is motivated by our analytic focus on how contexts of reception in a given environment shape the composition of a non-profit sector.
} 
IOSs are limited to the metropolitan areas where they are located - i.e., Toronto and NYC. IOSs have a complex geometry shaped by the overall size of the organizations' infrastructure, their programmatic focus, and their level of influence and sociopolitical recognition (i.e., status) in the immigrant community and receiving society. ${ }^{5}$

The Pakistani IOS is the universe of not-for-profit, Pakistani-led organizations in metropolitan Toronto or NYC offering services to or representing the Pakistani migrant community in each city. Given the variations across the organizational environments, as well as the ethno-national, religious, historical, and geographical boundaries in which the two Pakistani IOSs are embedded, this study investigates the extent of variance in their size, programmatic domain of action, and overall geographic scope.

\section{Contexts of Reception and Immigrant Organizations}

Portes and Rumbaut (2006, 1996) explain how migrants' modes of incorporation are shaped in part by contexts of reception. Four dimensions form these contexts including: statecentered policies of the host government; migrants' socioeconomic incorporation into the labor market; community socio-demographics; and the perceptions the dominant society has of the immigrant group. The unanimous consensus seems to be that the legal, cultural, economic, and social conditions immigrants encounter upon arrival greatly shape their fate in their new homelands (Castles 2000; De Haas 2010; Portes and Böröcz 1989; Portes and Rumbaut 2006).

\footnotetext{
${ }^{5}$ We define the size of the Pakistani organizational space by number of organizations. While alternative interpretations of organizational density or size could rely on numbers of members, we rely on the number of organizations because many non-profit organizations use a non-membership model (Johnson 2014) and we do not have complete data on membership rolls for the majority of organizations in the database. As a result, we follow conventions in previous research by using a count of the number of organizations to measure the overall size of the organizational space.
} 
However, such contexts are not absolute conditions that equally affect each and every immigrant group in the same way. Moreover, contextual conditions of reception have significant effects not only on individual immigrants' socioeconomic incorporation (Bauer, Lofstrom and Zimmerman 2001; Boswell 2003; Brubaker 2010; Geddes 2003; Portes and Rumabut 2006), but also on their likelihood to remain transnationally engaged with their homelands (Guarnizo and Chaudhary 2014; Guarnizo, Portes and Haller 2003). Recent research on the prevalence and effectiveness of immigrant organizations examines how contextual conditions in the host society affect immigrants' organizational capacity (Ramakrishnan and Bloemraad 2008). Each of the four dimensions of the context-of-reception framework may help explain variations between the Pakistani IOSs in Toronto and NYC.

\section{State-Centered Policies}

Existing research on immigrant organizations documents how the contextual environments shaped by state policies partially explain the size and composition of a given migrant group's organizational infrastructure. Structural and institutional contexts "from above" seem to equally impact not only organizations providing services to local immigrant communities (Bloemraad 2005, 2006; Breton 1964; Schrover 2006), but also those supporting transnational endeavors (Lacroix 2011; Portes, Escobar and Radford 2007; Portes and Zhou 2011; Smith and Bakker 2008). The state policies and associated narratives of national membership relevant for the present analysis are the official state-sponsored multiculturalism observed in Canada and the more laissez-faire assimilationist approach of the United States (see Bloemraad 2006, 2005 for a similar comparison of US and Canadian state policy). 
Different state policies may explain how migrants from the same country of origin experience divergent levels of incorporation, civic participation and organizational capacity in different host countries (Bloemraad and Wright 2014; Koopmans et al. 2005). For instance, Bloemraad's (2005) comparative research on Vietnamese and Portuguese immigrant organizations in Toronto and Boston finds that the Canadian government's official multiculturalist polices, which are considered the most inclusive state-sponsored approach to immigrants among all Western liberal democracies (see Kymlicka 1995), offer symbolic and material support to immigrant organizations. Bloemraad (2005) argues the Canadian approach explains why there is more immigrant organizational capacity between these two groups in Canada than in the United States.

Indeed, the United States does not have a comparable government policy for immigrant integration. While NYC may be considered multicultural in a demographic sense, like other U.S. immigrant gateway cities with high levels of ethnic diversity, it does not have official policies or a philosophy akin to state-sponsored multiculturalism (see Bloemraad and Wright 2014; Wright and Bloemraad 2012). ${ }^{6}$ In contrast to Canada, in the United States, the century-old model of assimilation continues to be the dominant national ideology advocated by the government, politicians, and U.S.-based immigration researchers (Kivisto and Faist 2010). The latter generally employ assimilationist models, which under-theorize the role of the state by focusing

\footnotetext{
${ }^{6}$ We do not use 'assimilationist' and 'multiculturalism' in a normative sense, but to refer to the official government policy discourses related to immigrant incorporation. For a detailed discussion of the different interpretations of multiculturalism see Bloemraad and Wright (2014).
} 
exclusively on individual attributes such as human capital and sociocultural distance between newcomers and the dominant society (Chaudhary 2015a; Waters and Jimenez 2005).

Schrover and Vermuelen (2005) argue that in addition to government policies, the size of an immigrant community is a key factor in explaining the focus and stability of immigrant organizations. However, they add, the relationship between state intervention and group size is not linear. Somewhat contradicting Bloemraad's (2005) argument, they contend that too much state intervention leads to reduced organizational activity. Similarly, communities that are either too small or too large experience problems in maintaining stable organizations.

Evidently, there is not a clear consensus on which national approach, the laissez-faire 'assimilationist' or the state-sponsored 'multiculturalist,' is more conducive to promoting the organizational capabilities of immigrants. Yet, the view that multicultural nations exhibit higher organizational membership and political participation among immigrants than non-multicultural nations seems predominant with respect to North America (Bloemraad 2006, 2005; Breton 2012; Kesler and Bloemraad 2010; Wright and Bloemraad 2012). Following Bloemraad's (2005) argument, it is hypothesized that:

H1-A: Because of the official multicultural context of reception, the Pakistani organizational space in Toronto is proportionally larger than that in NYC.

H1-B: Because of the official multicultural context of reception, the Pakistani organizational space in Toronto is more organizationally diverse than that in NYC.

While previous research on immigrant organizations offers insights into how statecentered contexts of reception may affect the size and diversity of an immigrant group's 
organizational space, the literature reviewed thus far does not explain how they might be associated with the geographic scope of an IOS. To what extent are state-sponsored multiculturalism or laissez-faire assimilationism more or less likely to be associated with a transnational orientation? The vast literature on transnational communities and diasporas assumes migrants are more likely to be motivated to engage in the social, economic and political issues of their homelands in receiving societies with commitments to the acceptance of cultural differences (see Koopmans et al. 2005:127). In other words, state-sponsored multiculturalism in societies such as Canada or Sweden may enhance a migrant community's transnational connections to their homelands (Akesson 2011). Similarly, research examining criticism of state-sponsored multiculturalism in the case of Canada finds that migrant communities may be more likely to engage in what critics refer to as 'unhealthy' transnational engagement due to their split loyalties and the weakening of a national identity (Stazewich 2007).

In their analysis of transnational 'claims-making', Koopmans et al. (2005) find that migrants' transnational activities are more frequent in countries without official policies of multiculturalism such as Germany and Switzerland—challenging the notion that such policies are associated with greater transnational engagement. In contrast, Akesson (2011) finds that multiculturalism in Sweden encourages transnational family relations among second-generation Swedish-Cape Verdeans. In brief, there is no consensus on whether state-sponsored multiculturalism increases or decreases transnational activities. However, based on the viewpoints of both proponents and opponents of official multiculturalism, it is expected that: 


\section{H1-C: Because of the official multicultural context of reception, the Pakistani organizational space in Toronto is more transnationally oriented than that in NYC.}

Finally, as discussed above, recent studies have demonstrated that immigrants' degree of legal incorporation into the receiving polity plays a crucial role in predicting their organizational capabilities. Smith and Bakker (2008), for example, concluded that the leadership of the transnational organizations they studied 'is largely the domain of migrants who have established an economic foothold in the United Sates and acquired US citizenship, rather than the domain of the poor and undocumented' (208). It is plausible then to expect that for Pakistani communities:

H1-D: The higher the proportion of naturalized Pakistani citizens, the greater the proportion of transnational organizations in the Pakistani organizational space.

It is important to notice, however, that most of these studies limit the meaning of the context of reception to the receiving society's state policies and national membership ideology. This analytical approach undoubtedly has significant shortcomings, for, as Schrover and Vermeulen (2005) have rightly indicated, it neglects or minimizes the other critical contextual dimensions (i.e., the immigrant community's labor market incorporation and resources and the dominant society's perception of the newcomers) that help shape immigrants' capacity to construct an organizational space.

\section{Socioeconomic Incorporation}

The second contextual dimension shaping immigrants' mode of incorporation and, thus, their organizational capabilities is the condition of the labor market and their participation in it. Immigrants' individual human capital and marketable skills to a great extent determine their 
socioeconomic fate. Civic leadership, both at the local and transnational levels, more often than not emerges from the ranks of the better off (Verba et al. 1995). This pattern has been found among different immigrant groups in the United States (Portes, Escobar and Radford 2007; Smith and Bakker 2008). Thus, it is plausible to expect that the better-off the group is, the more likely it is to have a higher organizational capability - i.e., a larger organizational space.

However, half a century ago, renowned Canadian sociologist Raymond Breton (1964) argued that the opposite was true; that is, the larger the proportion of poor people among an immigrant group, the more likely the group will be to have a large and diverse set of organizations. This conclusion, based on his study of thirty immigrant groups in Montreal before the official adoption of multiculturalist policies, was informed by the logic of increasing needs, rather than that of increasing resources, as more recent scholarship has shown in the case of the United States. As Breton puts it, 'If a large proportion of the members of an ethnic group have few resources of their own, as indicated for instance in rural origin and lack of occupational skills, then there is in this ethnic group an important "clientele" to support welfare and mutual benefit organizations'. Accordingly, unmet group needs represent an opportunity that a 'social entrepreneur' will seize by organizing 'something for the new immigrants in need.' Indeed, in his study he found 'a strong positive relationship $[\ldots]$ between the proportion of manual workers in an ethnic group and the degree of institutional completeness of that group' (Breton 1964: 204). By institutional completeness Breton (1964) refers to the relative ability of the immigrant community's organizations to provide all the services required by their members for everyday life. As such, institutional completeness ranges from zero immigrant organizations to a 
set of organizations able to provide education, religious services, health care, work, and so forth. Of course, absolute institutional completeness is an ideal type that cannot be found in reality. However, Breton's central analytical point is that the higher the degree of social isolation and alienation of the immigrant group within the receiving society, the higher its degree of institutional completeness. This conclusion is the antipode of that presented by contemporary analysts of locally-focused immigrant organizations, as discussed in the last section.

In order to test these contradictory arguments regarding the meaning of immigrant groups' institutional completeness, or organizational capacity, it is essential to include, in addition to state policies and membership principles, measurements of the group's socioeconomic attainment in its place of settlement. Therefore, it is hypothesized that, comparing the Pakistani communities in Toronto and NYC:

H2-A: The higher the average human capital of the local Pakistani community, the larger its total organizational space.

H2-B: The higher the median income of the local Pakistani community, the higher the proportion of transnational organizations.

H2-C: The higher the poverty rate among Pakistanis, the higher the degree of local institutional completeness.

\section{Immigrant community}

Social research indicates that an immigrant community's size, resources, and relative newness are significant factors molding its ability to organize and determining the viability of its immigrant organizations. Yet, the direction and meaning of such relationships are still in dispute. Scholars agree that the larger the community, the larger the number of potential 
members and clients that immigrant organizations would have - even heeding Schrover and Vermeulen's (2005) argument that there is a non-linear relationship between group size and organizational capacity. Based on these arguments, and keeping in mind that the Pakistani population in Toronto is much larger (Table 1) than that in NYC, it is hypothesized that, again,

H3-A: The Pakistani organizational space in Toronto is larger than that in NYC due to the larger size of the Pakistani community.

In addition, time since arrival appears to play a significant role in the group's organizational capability. Echoing Breton's (1964) argument, Bloemraad (2005: 881) argues that newer immigrants 'have a greater need for settlement and social services than an older immigrant group.' Therefore, newer immigrants are more likely to build organizations than older ones. We should thus expect that:

H3-B: The larger the proportion of recent Pakistani arrivals, the larger the local Pakistani organizational space.

\section{Dominant society}

Finally, perceptions and attitudes toward immigrants by the larger host society are an essential part of the newcomers' context of reception (Portes \& Rumbaut, 2006, 1996). The host society's hostility toward outsiders can affect how and where immigrants settle and what kinds of jobs and opportunities are made available to them. Depending on the host society's perception of the new entrants, immigrants may face more discrimination than others based on the color of their skin, their country of origin, or their religion. In some cases, the negatively perceived characteristics may be exacerbated by the group's size. Zolberg and Woon (1999) 
contend that the size and visibility of the Mexican immigrant community in the United States results in more discrimination and hostility than is experienced by other groups; two years before the September 11, 2001, attacks, their paper argued that Muslim immigrants in Europe were facing similar prejudice for the same reasons.

World events can also shift societal attitudes toward particular groups of immigrants. In the wake of $9 / 11$, most Western countries introduced new policies restricting immigration from Muslim countries, while in countries like the United States, where Arabs and Muslims used to be 'invisible,' they overnight became subject to close scrutiny and stigmatized as potential terrorists (Cainkar 2002; Cesari 2010; Jamal and Naber 2008; Peek 2011; Tirman 2004). Due to the 9/11 attacks and the intensity of the anti-Muslim backlash in NYC, there seems to be more hostility directed towards Pakistanis in NYC than in Toronto. How might such hostility affect the programmatic focus or spatial scope of Pakistanis' organizations in NYC? Breton (1964) offers an appealing answer to this question. He contends that sociocultural characteristics that differentiate an immigrant group from the host society lead to difficulty of acceptance and reduced socioeconomic mobility of immigrants and thus 'constitute the basis for the formation of a clientele $[\ldots]$ for ethnic organizations.' He further argues that 'This is particularly true - or perhaps only true - when the differentiating features are negatively evaluated by the native community' (204). Breton's reasoning leads us to hypothesize that,

H4-A: Because of the hostility directed towards Pakistanis following the 9/11 attacks, the Pakistani organizational space in NYC is significantly larger than that in Toronto. 


\section{Group Selection-Pakistani Immigrants}

Despite their growing significance, Pakistani immigrants represent a relatively understudied ethnic group in North America. This is especially surprising given increasing scholarship on Muslims in the West and the fact that Pakistanis comprise the largest Muslim immigrant community in North America. ${ }^{7}$ During the past decade a handful of studies examining the lived experiences of the North American Pakistani community have emerged. Yet, much of this research is limited to issues of identity and how Pakistanis respond to the post-9/11 hostile environment in their day to day lives (Ameeriar 2012; Rana 2011; Maira 2009, 2004;

Mohammad-Arif 2009). Very few studies examine how the 'war-on-terror' environment has affected organizational spaces of Pakistanis in North America (for an exception see Najam 2006). ${ }^{8}$

Large scale Pakistani migration to North America began in the 1970s. ${ }^{9}$ Historically, most Pakistanis identify themselves as Muslims, both in Pakistan and abroad (Bolognani \& Lyon 2011; Mohammad-Arif 2009). The first waves of Pakistani migrants to North America were high-skilled professionals such as doctors, scientists, entrepreneurs and students. Subsequent waves throughout the 1980s and 1990s represented a more diverse range of migrants, including

\footnotetext{
${ }^{7}$ According to the PEW Research Center's 2011 survey of American Muslims, foreign-born Pakistanis comprise the largest group of Muslims in the United States. According to the 2006 Canadian census, Pakistanis are the largest foreign-born group self-identifying as Muslim in Canada.

${ }^{8}$ It should be noted that Bakalian and Bozorgmehr (2009) study the effects of post-9/11 backlash on Muslim community-based organizations in the United States. However, the study does not focus on any particular ethnonational groups nor on a particular city.

${ }^{9}$ The first Muslim migrants from the Indian subcontinent migrated to the west coast of Canada and the US in the late $19^{\text {th }}$ century. Although the vast majority were Punjabi Sikhs, many were also Punjabi Muslims who were later categorized as Pakistanis following Independence and Partition in 1947 (Das Gupta 2006; Jensen 1988). The bulk of Pakistani migration to North America occurred in the 1970s following the liberalization of US and Canadian immigration policies in the mid to late 1960s (see Mohammad-Arif 2009, 2002).
} 
professionals as well as low-skilled migrants reuniting with family members. By the 1990s, the Pakistani migrant communities in Canada and the United States were experiencing divergent levels of incorporation.

\section{Site Selection}

Both Toronto and NYC are paradigmatic symbols of the immigrant-rooted national narratives of their respective countries, with long traditions of serving as gateways to North America and facilitating the incorporation of countless immigrant groups. These two metropolises are home to the largest Pakistani immigrant communities in Canada and the United States, respectively (2006 Canadian Census; 2013 U.S. Current Population Survey).

Historically, however, the two cities diverge with respect to their national and local state policies of immigrant integration and their local contextual environments - particularly since the $9 / 11$ attacks.

Following 9/11, NYC simultaneously became the symbolic epicenter of the moral panic surrounding international terrorism and the focal point of U.S. domestic counter-terrorism policies and practices (Apuzzo and Goldman 2013; Nguyen 2005). The Pakistani community experienced first-hand the effects of counter-terrorism-inspired enforcement, including unpleasant encounters in a variety of everyday experiences (see Das Gupta 2006; Nguyen 2005). Hundreds of Pakistani migrants were rounded up, detained and eventually deported due to minor immigration violations in the two years following the 2001 attacks (Mohammad-Arif 2009; Nguyen 2005). Recent journalistic investigations have also revealed the New York Police Department's widespread covert surveillance program targeting public meeting places 
frequented by Pakistani migrants, such as cafes and mosques, as part of numerous investigations seeking to uncover potential "homegrown" terrorists (Appuzzo and Goldman 2013; Greenberg 2012). The Pakistani community and its organizations soon found themselves experiencing a collective fear, alienation and precariousness related to the growing stigma linking Pakistanis with religious extremism and terrorism (Mohammad-Arif 2009; Najam 2006; Nguyen 2005).

Meanwhile, Toronto, and Canada in general, lack direct experiences with terrorism on the massive scale of 9/11. As the metropolitan symbol of Canada's official policies of multiculturalism, Toronto projects a model of acceptance and inclusion that appears to contradict the exclusionary politics and policies associated with post-9/11 NYC. Yet, the global scope of the U.S.-led 'war on terror' contributes to an increasing use of surveillance and negative media stereotyping directed towards Islamic extremism within Canadian society (Steuter and Wills 2009). This has lately contributed to the emergence of stigma directed towards Pakistanis and Muslims in general within Canadian society (Ameeriar 2012; Kazemipur 2014), albeit not yet quite to the levels experienced and documented in NYC and the United States (Chaudhary 2015b).

\section{DATA AND METHODOLOGY}

Data were collected in two phases over an 11-month period in 2013. The first phase sought to determine the size, composition, and spatial scope of the Pakistani IOSs in metropolitan Toronto and NYC. In order to do so, a new database consisting of the universe of registered Pakistani immigrant-serving non-profit organizations was constructed using national databases of non-profit organizations in each metropolitan area. This data collection strategy 
replicates that of previous studies by relying on comprehensive databases such as the U.N. Directory of Non-Governmental Organizations, Associations Unlimited (previously The Encyclopedia of Associations) and GuideStar (see Lacroix 2011; Ramakrishnan and Bloemraad 2008; Okamoto 2006 for examples using these same sources). Organizations that are Pakistani or serve the Pakistani community were identified by searching for organizations with Pakistani, Muslim/Islamic or South Asian identities. In the case of Muslim and South Asian organizations, each organization was closely examined and included only if it did in fact represent or offer services to Pakistanis.

It should be noted that large databases such as the ones used here are notorious for undercounting immigrant organizations. To correct for possible undercounts, supplemental information about Pakistani organizations in each city was collected through in-depth interviews with key informants, consultation of ethnic directories and media, and intensive web searches. While it is possible that the databases used here could have missed some organizations, such subenumeration is surely minimal in both cities. Any missed organizations would most likely be very few, very small and informal; thus, their exclusion does not significantly affect our findings.

The overall number of organizations in each organizational space is used to measure its size. Counts of organizations are a conventional approach used in previous research on immigrant and ethnic organizational density or capacity—especially when membership or financial information is not available or accessible (see Bloemraad 2005; Breton 1964). In addition, counts of organizations are a better proxy than organizational membership numbers because many immigrant and ethnic organizations do not have traditional memberships. The 
non-membership associational form is especially common in the United States (see Johnson 2014), making counts the only reliable way to compare overall size and organizational capacity between the US and Canada. Once the main list was constructed, each organization was coded and categorized according to its year of foundation, programmatic domain of action (social services, advocacy/politics, economic development, culture, or religion) and geographic scope of services/activities (local or transnational). This database provides the core evidential information to compare the Pakistani organizational spaces in the two cities.

The second phase was designed to gather first-hand qualitative information on the inner working conditions, everyday experiences, and general landscape of the Pakistani organizational space in each metropolitan area. It consisted of 84 in-depth interviews with organization leaders and executives, government officials, community leaders, and key informants, including scholars and non-Pakistani local residents who could provide information about the target population and their organizations. Organization leaders and executives were selected using a stratified random sample of organizations in each metropolitan area drawn from the complete database of organizations, in order to reduce possible homogeneity among the interview respondents. The local universe of organizations was stratified according to main domain of action and assigned unique identifiers. Random samples were then drawn within each domain. The first organization in the random list was contacted to set up an interview. In cases when the selected organization did not respond to three attempts at contact, the organization was removed and the second organization in the random list was contacted. In general, contact was made by the third attempt, yielding a response rate of 73 percent. 
All interviews were conducted in English and lasted an average of 1.5 hours, with some of them lasting as little as 45 minutes and others as long as 3 hours. In addition to the in-depth interviews, the first author conducted over 200 hours of observation in Toronto and NYC, attending organization sponsored events and meetings in order to gain a first-hand perception of the dynamics within each organizational space - paying particular attention to inter- and intraorganizational relations, as well as relations between organizations and the local community.

\section{RESULTS}

\section{Comparing Immigrant Communities}

The Pakistani communities in Toronto and NYC share some striking similarities in their sociodemographic characteristics, but dramatically differ in their socioeconomic mode of incorporation. As data in Table 1 indicate, although the Pakistani population in Toronto is 2.5 times as large as that in NYC, the populations have a similar gender composition (47.5 percent and 45.4 percent women, respectively), an identical median household size (four members), and very high levels of homeownership and human capital. Indeed, while the proportion of Pakistani New Yorkers holding at least a college degree is five percentage points higher than that of Pakistanis in Toronto (47.4 percent vs 42.3 percent), these proportions of highly educated Pakistanis are substantially higher than those of the general population in each city (32.0 percent in NYC and 26.8 percent in Toronto). Evidently, this is a very select group, not only in relation to the receiving societies, but most especially in relation to Pakistan, a country that according to UNESCO has some of the worst education indicators globally and ranks 113 out of 120 countries in the Education Development Index (UNESCO 2012). Pakistani immigrants in both cities have 
also relatively high levels of labor force participation (66.8 percent in Toronto and 60.0 percent in NYC), very close to those of the local general population (68.1 percent and 61.7 percent in Toronto and NYC, respectively). But it is here where the similarities end, for the paths of socioeconomic incorporation of the two immigrant populations take them in sharply different directions.

Despite their similarly high levels of human capital and labor force participation, and notwithstanding Toronto's officially welcoming multicultural environment, Pakistanis in Toronto appear to fare far worse than both their co-nationals in the Big Apple and the Toronto population as a whole. In Toronto, Pakistanis' median per capita income is just 85 percent that of their co-nationals in New York City and just 48 percent that of the Toronto population (see Table 1). Meanwhile, Pakistani New Yorkers' median per capita income is 89 percent that of NYC as a whole. These differences appear more acute when we look at median household income, which is a better indicator of a group's economic attainment. Pakistanis in New York basically earn the same median household income as New Yorkers in general (US\$68,000), while those in Toronto earn around two-thirds of the median household income of Toronto as a whole (approximately US\$52,000).

The unequal economic rewards that Pakistanis receive for their high human capital are reflected in the startlingly different socioeconomic conditions they experience in the two metropolises. While those in New York City have a poverty rate slightly higher than the general population's (14.4 percent versus 13.6 percent), a staggering 40 percent of their Toronto counterparts live in poverty, more than twice the total rate for Toronto (see Table 1). It is worth 
emphasizing here that Pakistanis in Toronto experience such a high rate of poverty despite their higher labor force participation and lower unemployment rate than their counterparts in NYC. ${ }^{10}$ This suggests their high poverty rate is not because of a lack of economic participation or lack of employment, but because they earn too little for their labors - a result of either labor force mismatch (i.e., being underemployed and thus underpaid vis-à-vis their high qualifications) or labor market discrimination. An alternative explanation could be their relatively recent period of arrival, for nearly one-fourth of the Pakistanis in Toronto arrived after 2001, while just around one-sixth of Pakistanis in New York have arrived since that year. Determining the factors shaping this process is beyond the scope of this paper. Nevertheless, what the evidence presented reveals is that, contrary to our initial expectations, Toronto's officially multicultural environment appears less inclusive in socioeconomic terms than assimilationist NYC.

- Table 1 around here -

Notwithstanding these aggregate differences, direct observations for this study, as well as results from previous research, indicate that the Pakistani community in both cities is deeply fragmented between a small affluent professional class and a growing, impoverished working class toiling in the service sector as taxi drivers, retail clerks, petty merchants, and gas attendants. Such social fragmentation appears to be more acute in Toronto than in NYC (Fieldwork notes; Das Gupta 2006; Mohammad-Arif 2009, 2002). It is in these disparate and

\footnotetext{
${ }^{10}$ It should be noted that the poverty rate as calculated in the U.S. data and the low income measure used in the Canadian census are not the same. The U.S. value reflects the number of Pakistani immigrants with a total income below the official poverty line, while the Canadian data represent the proportion of Pakistani immigrants who are considered "low income". Yet in both cases these data reflect the overall economic incorporation of Pakistani immigrants relative to the total populations in the two cities.
} 
stratified socioeconomic conditions that these Pakistani populations have managed to construct diverse and vibrant, albeit very different, organizational spaces.

\section{Comparing Immigrant Organizational Spaces}

Neither a supportive state multicultural context, nor group size nor human capital resources seem to work in favor of Pakistanis in Toronto vis-à-vis Pakistani New Yorkers regarding their organizational capacity. As Table 2 shows, the Pakistani IOS in Toronto has fewer organizations in absolute and relative terms than that in NYC. The total number of immigrant organizations in Toronto (54) represents just three-fourths of the number in NYC (71). Given the significant difference in the size of the two communities, the rate of organizations per thousand immigrants provides a more accurate comparison of the level of organizational capacity between the two spaces. Results, presented at the bottom of Table 2, show that the difference is surprisingly large; Pakistani New Yorkers have an organization rate 3.2 times higher than their compatriots in Toronto ( 1.77 versus .56 organizations per thousand immigrants, respectively).

These results challenge hypothesis H1-A predicting that the organizational space would be larger in Toronto due to the more inclusive official multicultural context. Similarly, these findings refute hypothesis $\mathrm{H} 3-\mathrm{A}$, which also predicted greater organizational capacity in Toronto due to the larger size of its Pakistani community, as well as hypothesis H3-B, according to which immigrants' organizational capacity is positively related to the proportion of recent arrivals. This does not seem to be the case, since the proportion of recent arrivals (since 2001) in Toronto is higher than that in New York City. However, these results do lend support to hypothesis H4- 
A, which expects Pakistani New Yorkers to possess a larger organizational space than their conationals in Toronto as a result of the hostile post-9/11 environment they confront.

In sum, these initial results strongly suggest that, contrary to expectations drawn from previous studies, an active, inclusive multiculturalist state is not enough to promote immigrants' organizational infrastructure. So far, findings actually support the opposite, namely, that it is in the less engaged state-centered policy environment that Pakistani organizations seem to flourish - which is consistent with previous comparative research finding higher levels of civic engagement and claims-making in countries lacking official multiculturalism policies (Koopmans et al. 2005). This leads us then to inquire to what extent Pakistanis' socioeconomic resources affect the formation of organizational spaces.

At first glance, the differences in the organizational spaces between the two locations seem to be explained by the higher human capital in NYC, as described in hypothesis H2-A. While this is plausible, it could be argued that the difference in human capital (a mere 5 percent higher proportion of highly educated Pakistanis in NYC than in Toronto) cannot fully explain the gargantuan difference in organizational capacity ( 3 to 1 ) between the two cities. This leads us to look into another dimension of the Pakistani migratory experience.

Evidently, the strongest explanation for the Toronto-NYC organizational difference seems to be the disparate modes of incorporation Pakistanis experience in the two cities. As discussed earlier, Pakistanis in Toronto earn much lower individual and household median incomes, have very high rates of poverty, and tend to have less access to homeownership, the most important financial asset for average North American families. This situation, however, 
seems to have two different, contradictory effects. On the one hand, it limits the size of Toronto's organizational space. On the other, as predicted by hypothesis H2-C, and in accordance with Breton's (1964) expectation, a higher poverty level leads to a greater degree of institutional completeness within the organizational space.

- Table 2 around here -

\section{Institutional Completeness: Diversity of Programmatic Domains}

Results regarding the diversity of organizations (i.e. level of institutional completeness) in the two IOSs suggest Pakistani organizations are more evenly distributed across programmatic domains of action in Toronto than in NYC (see columns 1 and 3, Table 2). Indeed, the Toronto Pakistani organizational space contains roughly similar numbers of social, political, cultural, economic, and faith-based organizations. This confirms the predictions of hypothesis H1-Bthat multiculturalism policies are associated with more organizational diversity. Findings also confirm hypothesis $\mathrm{H} 2-\mathrm{C}$ - that poorer immigrant communities are more likely to have a higher degree of institutional completeness. Incidentally, the proportion of secular organizations providing cultural services to Pakistanis in Toronto is twice as large as that in NYC, where cultural outfits represent the smallest proportion of organizations.

The organizational space in NYC is dominated by religious organizations, which represent over half of the total. In contrast, Toronto's organizational space is much more secular, with just one-fifth faith-based organizations (see Table 2). The apparent 'overrepresentation' of religious organizations in NYC should not be seen as surprising. Rather, what is surprising is the predominance of secular organizations in the Toronto organizational space, for multiple studies 
have documented the central role religious organizations have played in facilitating the settlement process of immigrants throughout North American history up to the present (Breton 2012; Hirschman 2004; see also Min 2010; Levitt 2007). It is highly plausible that the secularized organizational space of Toronto may be a result of the multiculturalism of Canada's and Toronto's government policies. Conversely, the lack of diversity within the NYC organizational space due to the dominance of religious organizations may be a result of the U.S. and NYC governments' 'hands-off' approach to immigrants and immigrants' historical tendency to rely on religious organizations instead of the state to gain access to socioeconomic services.

\section{Geographical Scope}

The vast majority of organizations forming the Pakistani organizational spaces in both Toronto and NYC are local service providers. Which organizational space contains the largest proportion of transnational Pakistani organizations? It was expected that Toronto would because of the inclusive, multicultural context (hypothesis H1-C). It was also expected that the city with Pakistani migrants with higher rates of naturalization (H1-D) and a higher median income (hypothesis H2-B) would be the home of a more transnationally focused organizational space.

As Table 2 shows, NYC's Pakistani organizational space is actually more transnational than Toronto's, with a full one-fifth transnational organizations, as compared to Toronto's oneeighth. This result refutes hypothesis H1-C. However, it lends support to hypotheses H1-D and H2-B, for NYC's Pakistani community has a higher median income and a higher naturalization rate than its counterpart in Toronto. Again, keeping in mind the different contexts of reception, it is plausible to conclude that the spatial scope of Pakistani organizational spaces is mostly 
shaped by immigrants' mode of incorporation, rather than by state policies and ideologies of national inclusion. Contrary to expectations, the material and symbolic support of state multiculturalism appears to stymie rather than encourage the formation of transnational organizations, while enhancing organizations aiding with local incorporation processes. Conversely, organized transnational activism seems more likely to develop in a context of reception in which the state refrains, for the most part, from aiding immigrants.

\section{Internal Dynamics and Tensions}

The interaction between state policies and immigrants' modes of incorporation is further substantiated by data gleaned through interviews with Pakistani organization leaders. The perceptions and socioeconomic polarization within the two Pakistani communities are reflected in tensions observed between the leaders of local and transnationally-oriented organizations in both Toronto and NYC. The strategies adopted by local and transnational organizations are interrelated as they are embedded in the same structural contexts that also include the receiving state's interest in their homeland. This is nicely captured in the comments provided by a leader of a transnational Pakistani charity in Toronto, who, when asked about his organization's source of funding, explained:

We have to rely on donations from the community for our work in Pakistan. You see, these big social service organizations get all of the grants. You get a few Pakistanis or South Asians together and make a Board. Then you get [official] non-profit or charity status and make sure your mission is about integration. That's it! Then you can get all of the government grants for multiculturalism. But for us? We don't get those funds. We want to help poor villages in Pakistan and help improve our homeland. There is no government help for us. The aid money the government gives goes to big NGOs who are in cahoots with the UN. It'd be easier to throw a bunch of dances, or have a big dinner, then we could get grants and say we are doing multiculturalism. 
These comments reflect a common, albeit unfounded, beliefs among transnational organization leaders in Toronto that integration focused organizations are obtaining large grants through official multiculturalism programs. While the symbolic support offered by state policies and programs associated with official multiculturalism may tend to favor locally-oriented organizations, there was little evidence that integration organizations were recipients of major government funding schemes.

If the lower proportion of transnational organizations in Toronto can be explained by the Canadian state's multicultural intervention, perhaps the higher proportion of transnational organizations in NYC could be explained by the state's lack of action. However, a closer analysis reveals the key role migrants' modes of incorporation play in the process. Funding for organizations in NYC is primarily a function of corporate and individual donations. Since the Pakistani community there is, on average, more affluent than that in Toronto, its transnational organizational space ends up being comprised of more organizations.

Evidently, transnational organizations are the exclusive domain of the better off in both cities. Observations indicate wealthy Pakistanis have many ties to transnational organizations promoting economic and social development in Pakistan. The better off can afford to participate in and co-sponsor transnational organizations to facilitate their personal, economic, political, or nationalist interests. The poor, even if they would like to, often cannot afford it -because of either lack of resources or lack of time due to the long working hours required to survive in North America. This finding coincides with what has been observed in the case of individual 
transnational political engagement (Guarnizo, Portes, and Haller 2003; Guarnizo and Chaudhary 2014; Smith and Bakker 2008).

Disparate class origins and the uneven competition for scarce financial resources contribute to tensions between transnational and locally focused Pakistani organizations. Approximately 70 percent of the interviewees from organizations focusing on their respective local Pakistani communities expressed resentment towards the often larger and better funded transnational organizations. This sentiment is well captured in the remarks of a 46-year old female director of a Pakistani social service organization in New York:

Those rich Desi's just pretend like there are no problems here. The Imams do the same. They all want to send their money and volunteer their time to help poor people in Pakistan, but don't want to lift a finger to help Pakistanis suffering here in New York. Many of them act like big shots when they go back to Pakistan...they'll say, 'look at all the good I have done for the country, show me some respect!' It's bad enough that the foundations and the city don't give us anything, but when you have these rich Pakistanis doing the same thing, it really hurts and shows you how divided the community is between the haves and have nots.

Similar frustrations with transnational organizations were also found among locally-oriented

Pakistani organizations in Toronto. As a member of the executive board of a Pakistani

organization working on housing issues in Toronto explained:

There is this myth that the government funds ethnic organizations in Canada, but it just isn't true. Every time we apply for a government grant, we never get it! We rely mainly on donations. But the big [transnational] Pakistani charities have lots of big shots working for them. They use their connections to bring famous singers from Pakistan or something and hold big events and raise like 20,000 dollars in one night. We don't get the same kind of people at our events because rich Pakistanis here don't want to be bothered about other Pakistanis struggling here. They just focus their resources on Pakistan because I think they feel guilty for everyone they left behind. 
The comments above reflect how fund raising and donations pose practical challenges for all Pakistani organizations, regardless of their geographic scope of action. In general, the competition for scarce resources found in both the Toronto and New York Pakistani IOSs generated tensions between local and transnationally oriented organizations, reflecting the growing class polarization within both communities.

\section{DISCUSSION AND CONCLUSIONS}

Drawing on key perspectives from existing research, this study examined how multilayered contexts of reception shape the overall size, institutional completeness and geographic scope of Pakistani organizational spaces in Toronto and NYC. One of the most important findings is the counterintuitive effect of the context of reception on the size, diversity in programmatic action, and geographic scope of the organizational spaces. The inclusive state-sponsored multicultural context of reception associated with Toronto does not appear to be a strong positive factor promoting the formation of more organizations or organizational capacity, as previous studies have reported it to be. Conversely, a rather hostile post-9/11 context of reception ruled by a laissez-faire system of governance, coupled with successful socioeconomic incorporation, appears to have fostered the construction of a larger Pakistani IOS in NYC. In this sense, our results somewhat challenge Bloemraad's $(2005,2006)$ findings. However, our findings do not offer definitive evidence either for or against multiculturalism policies' being conducive to immigrants' organizational capacity. Rather, they suggest that particular opportunities and constraints associated with official multiculturalism policies may vary across different immigrant groups. 
Another key finding concerns the importance of moving away from analyses that overemphasize state policies in relation to immigrant organizations. Our findings indicate that the state's role by itself may not constitute a sufficient condition or explanatory factor for variation in size and composition across these two organizational spaces. Rather, the effects of state policies seem to be contingent on immigrants' mode of socioeconomic incorporation and internal social stratification. That is, a state-sponsored multicultural context of reception could prove insufficient to promote immigrant organizational capabilities if it is accompanied by an economic context that compensates immigrants' human capital unfairly. Conversely, the evidence suggests a labor market in which immigrants' human capital tends to be fairly rewarded may be associated with more organizational capacity and a more transnationally oriented organizational space, even if the immigrants encounter a hostile sociocultural reception.

It is very important to emphasize here that the particular composition of each Pakistani IOS could neither be attributed to nor explained solely by the community's social and human resources, as if they were dis-embedded, 'independent' variables. For such resources are embedded in specific contexts of reception in which they are variously valued or devalued. This explains why Pakistani communities possessing very similar human capital characteristics ended up experiencing very different social conditions and having quite different organizational spaces in Toronto and NYC.

In this sense, the size and composition of IOSs are mostly shaped by immigrants' mode of incorporation. Immigrant organizational capacities do not depend just on the state's action or omission, but rather on the resources their mode of incorporation allows them to build and accumulate upon arriving. Immigrants' mode of incorporation has to do with the way in which their 
presence is dealt with by the receiving society, not only in terms of perception and acceptance, but also in terms of access to the socioeconomic rewards enjoyed by native-born citizens.

Findings suggest that, contrary to expectations; Canadian multiculturalism does not foster a more transnationally oriented Pakistani organizational space. At first glance, it appears that the official symbolic and material support provided by the government to immigrant organizations may constrain them from pursuing issues and activities that transcend national borders. Our findings are consistent with Koopmans et al. (2005) in that the more restrictive assimilationist context of reception in NYC is associated with a greater number of transnational organizations. The evidence collected leads us to propose that it is the intersection between immigrants' mode of incorporation and state policies that better explains the unequal distribution of transnational Pakistani organizations.

Alternatively, it could be argued that the greater number of transnational organizations in NYC may be explained by the absence of official multiculturalism and that the lack of interaction between NYC-based organizations and the state translates into more organizational autonomy_enabling organizations to pursue a wider scope of action. However, such autonomy would never be possible to realize unless the Pakistani community accumulated enough disposable resources to finance transnational endeavors. State action or inaction by itself is not enough to spearhead IOSs, let alone organizations with a transnational scope.

IOSs are social spaces in which societal conditions are reproduced. As seen in the Pakistani case examined here, IOSs can also be conceived as arenas of both open and subtle power struggles and social tensions. These tensions, in turn, can have a strong impact on the 
size, composition and geographic scope of action of an IOS. This is especially apparent in regard to tensions between local and transnationally oriented Pakistani immigrant organizations. While processes of individual assimilation and transnationalism have been found to be complementary among Latin American migrants (Guarnizo et al 2003), at the level of organizations, these same processes present a different dynamic and character, as organizations providing local incorporation services are perceived as diametrically opposed to those involved in transnational activities. Their antagonism is, in part, explained by the fact that the two types of organizations represent different social groups and interests within the same immigrant, qua ethnic, group.

Moreover, both types of organizations are embedded in the same sociopolitical context, and thus inexorably end up competing for the same scarce resources in a process that irremediably exacerbates the original social divisions separating their leaders. Thus, Pakistani organizational spaces in Toronto and NYC reflect an assemblage of institutional policies, modes of immigrant incorporation and intra-group class polarization.

\section{AKNOWLEDGMENTS}

The authors would like to thank Irene Bloemraad, Fred Block and the editors at JEMS for their helpful comments and suggestions. Funding for this research came from a doctoral research grant awarded by the University of California Center for New Racial Studies and support from the Departments of Sociology and Human Ecology at the University of California, Davis. Earlier versions of this paper were presented in the 2014 at the Annual Meeting of the American Sociological Association in San Francisco and at the Fifth Annual University of California Conference on International Migration held at the Centre for Comparative Immigration StudiesUCSD. 


\section{REFERENCES}

Akesson,L. (2011) "Multicultural Ideology and Transnational Family Ties among Descendants of Cape Verdeans in Sweden" in Journal of Ethnic and Migration Studies. 37(2):217235.

Ameeriar, L. (2012). “The Sanitized Sensorium” in American Anthropologist. 114(3):509-520.

Apuzzo, M., and A. Goldman (2013) Enemies Within: Inside the NYPD's Secret Spying Unit and Bin Laden's Final Plot Against America. New York: Simon and Schuster.

Bakalian, A. and M. Bozorgmehr. (2009) Backlash 9/11: Middle Easter and Muslim Americans Respond. Berkeley: University of California Press.

Bauer, T. K., M. Lofstrom, and K. F. Zimmerman. (2001) "Immigration Policy, Assimilation of Immigrants and Natives's Sentiments towards Immigrants: Evidence from 12 OECD Countries." Center for Comparative Immigration Studies, UC San Diego Working Papers 04-01-2001.

Bloemraad, I. (2005). "The Limits of de Tocqueville: How Government Facilitates Organisational Capacity in Newcomer Communities." Journal of Ethnic and Migration Studies 31(5):865-87.

Bloemraad, I. (2006). Becoming a Citizen: Incorporating Immigrants and Refugees in the United States and Canada. Berkeley: University of California Press.

Bloemraad, I. and M. Wright. (2014) “ 'Utter Failure' or Unity our of Diversity? Debating and Evaluating Policies of Multiculturalism” International Migration Review. 48(1):292334.

Bolognani, M. and S.M. Lyon. (eds) (2011) Pakistan and Its Diaspora: Multidisciplinary Approaches. New York. Palgrave Macmillan.

Boswell, C. (2003) European Migration Policies in Flux: Changing Patterns of Inclusion and Exclusion. Oxford: Blackwell Publishing.

Bourdieu, P. (1992) “The Logic of Fields" in P. Bourdieu and L. Wacquant (Eds). An Invitation to Reflexive Sociology. Chicago: University of Chicago Press.

Breton, R. (1964) "Institutional Completeness of Ethnic Communities and the Personal Relations of Immigrants." American Journal of Sociology 70(2):193-205.

Breton, R. (2005) Ethnic Relations in Canada: Institutional Dynamics. Montreal: McGill -Queen's University Press.

Breton, R. (2012) Different Gods: Integration of Non-Christian Minorities into a Primarily Christian Society. Montreal: McGill-Queen's University Press.

Brubaker, R. (2010) "Migration, Membership, and the Modern Nation-State: Internal and External Dimensions of the Politics of Belonging. " Journal of Interdisciplinary History 61(1):61-78. 
Cainkar, L. (2002) "No Longer Invisible: Arab and Muslim Exclusion After September 11." Middle East Research and Information Project 224(Fall):22-29.

Castles, S. (2000) "International Migration at the Beginning of the Twenty-First Century: Global Trends and Issues." International Social Science Journal (165):269-81.

Cesari, J. (2010) Muslims in the West after 9/11, Religion, Politics and Law. New York: Routledge

Chaudhary, A.R. (2015a) "Racialized Incorporation: The Effects of Race and Generational Status on Self-Employment and Industry-Sector Prestige" in International Migration Review.49(2):318-54.

Chaudhary, A.R. (2015b) Spoiled By War: How Government Policies, Community Characteristics and Stigma Shape the Pakistani Non-Profit Sector in London, Toronto and New York City. Unpublished Doctoral Dissertation. Department of Sociology, University of California, Davis.

Cordero-Guzman, H. (2005). "Community-Based Organizations and Migration in New York City." Journal of Ethnic and Migration Studies 31(5):889-909.

Das Gupta, M. (2006) Unruly Immigrants: Rights, Activism, and Transnational South Asian Politics in the United States. Durham, NC. Duke University Press.

De Graauw, E. (2008) "Nonprofit Organizations: Agents of Immigrant Political Incorporation in Urban America" in Ramakrishnan, K. and I. Bloemraad (eds) (2008) Civic Hopes and Political Realities: Immigrants, Community Organizations, and Political Engagement. New York: Russell Sage Foundation.

De Haas, H. (2010). "Migration transitions: A Theoretical and Empirical Inquiry into the Developmental Drivers of International Migration." International Migration Institute, Working Paper WP24, University of Oxford U.K.

DiMaggio, P. J., and W.W.Powell. (1983). "The Iron Cage Revisited: Institutional Isomorphism and Collective Rationality in Organizational Fields." American Sociological Review 48(2):147-60.

Faist, T. (2000) The Volume and Dynamics of International Migration and Transnational Social Spaces. Gloucestershire: Clarendon Press. , M. Fauser., E. Reisenauer. (2013) Transnational Migration. Cambridge, U.K.: Polity

Foner, N., J. Rath, J.W. Duyvendak and R. van Reekum. (eds) (2014) New York and Amsterdam: Immigration and the New Urban Landscape. New York: New York University Press

Geddes, A. (2003) The Politics of Migration and Immigration in Europe. London: SAGE Publications. 
Gleeson, S., Bloemraad I. (2012) Assessing the Scope of Immigrant Organizations: Official Undercounts and Actual Underrepresentation. Nonprofit and Voluntary Sector Quarterly 42(2): 344-368.

Greenberg, M. (2012) "The problem of the New York Police." Pp. 14-16 in New York Review of Books.

Guarnizo, L. E., and A.R. Chaudhary. (2014) "Determinants of Transnational Political Engagement among Dominican and Colombian Migrants in Southern Europe." f International Migration Institute Working Paper WP82. University of Oxford.

Guarnizo, L. E., A. Portes, and W. Haller. (2003) "Assimilation and Transnationalism: Determinants of Transnational Political Action among Contemporary Migrants." American Journal of Sociology 108 (6):1211-48.

Hirschman, C. (2004) "The Role of Religion in the Origin and Adaptation of Immigrant Groups in the United States" International Migration Review. 38(3):1206-33.

Jamal, A., and N.C. Naber (eds) (2008) Race and Arab Americans Before and After 9/11: From Invisible Citizens to Visible Subjects. Syracuse, NY: Syracuse University Press.

Jensen, J. (1988) Passage from India: Asian Immigrants in North America. New Haven, CT: Yale University Press.

Johnson, E.W. (2014) "Toward International Comparative Research on Associational Activity: Variations in the Form and Focus of Voluntary Associations in Four Nations" in Nonprofit and Voluntary Sector Quarterly. 43(2):163-181

Kazemipur, A. (2014) The Muslim Question in Canada: A Story of Segmented Integration. University of British Colombia Press. Vancouver, BC. Canada.

Kesler, C., and I. Bloemraad. (2010) "Does Immigration Erode Social Capital? The Conditional Effects of Immigration-Generated Diversity on Trust, Membership, and Participation across 19 Countries, 1981-2000." Canadian Journal of Political Science 43(2):319-47.

Kivisto, P., and T. Faist. (2010) Beyond a Border: The Causes and Consequences of Contemporary Immigration. London: Pine Forge Press.

Koopmans, R., P. Statham., M. Giugni., and F.Passy. (2005) Contested Citizenship, Immigration and Cultural Diversity in Europe. Minneapolis.MN. University of Minnesota Press.

Kymlicka, W. (1995) Multicultural Citizenship. Oxford: Clarendon Press.

Lacroix, T. 2011. "Indian and Polish Migration Organization Fields." International Migration Institute, Working Paper WP40, University of Oxford. U.K.

Landolt, P., and L. Goldring. (2010) "Political Cultures, Activist Dialogues and the Constitution of Transnational Social Fields: Latin American and Canadian Organizing in Toronto." Global Networks 10(4):443-66.

Levitt, P. (2007) God Needs No Passport: Immigrants and the Changing American Religious Landscape. New York: The New Press. 
Maira, S. (2004) "Youth Culture, Citizenship, and Globalization: South Asian Muslim Youth in the United States after September 11th." Comparative Studies of South Asia, Africa and the Middle East. 24(1):219-231

Maira, S. (2009) Missing: Youth, Citizenship, and Empire after 9/11. Durham,NC. Duke University Press.

Marwell, N.P. (2004) 'Privatizing the Welfare State: Nonprofit Community-Based Organizations as Political Actors', American Sociological Review, 69(2): 265-91.

Min, P. G. (2010) Preserving Ethnicity Through Religion in America: Korean Protestants and Indians Hindu Across Generations. New York: New York University Press.

Mohammad-Arif, A. (2009) "Pakistanis in the United States: From Integration to Alienation?" in Pakistani Diasporas: Culture, Conflict and Change. (eds) Kalra,V.S. and Khan, A. Oxford, UK: Oxford University Press.

Mohammad-Arif, A. (2002) Salaam America: South Asian Muslims in New York. London: Anthem Press.

Moya, J.C. (2005) "Immigrants and Associations: A Global and Historical Perspective." Journal of Ethnic and Migration Studies 35(5):833-64.

Najam, A. (2006) Portrait of A Giving Community: Philanthropy by the Pakistani-American Diaspora. Cambridge, MA: Global Equity Initiative Asian Center, Harvard University

Nguyen, T. (2005) We Are All Suspects Now: Untold Stories from Immigrant Communities after 9/11. Boston, MA: Beacon Press.

Okamoto, D. G. (2006) "Institutional Pan-Ethnicity: Boundary Formation in Asian-American Organizing." Social Forces 85(1):1-24

Peek, L. (2011) Behind the Backlash, Muslim Americans after 9/11. Philadelphia: Temple University Press.

Portes, A. and L.D. Smith. (eds) (2012) Institutions Count: Their Role and Significant in Latin American Development. Berkeley: University of California Press.

Portes, A., and M. Zhou. (2011) "The Eagle and the Dragon: Immigrant Transnationalism and Development in Mexico and China." Center for Migration and Development, Princeton University Working Papers 12-03.

Portes, A., C. Escobar, and A.W. Radford. (2007) "Immigrant Transnational Organizations and Development: A Comparative Study." International Migration Review 41(1):242- 81.

Portes, A. and R.G. Rumabut. (2006, 1996) Immigrant America: A Portrait. Berkeley, CA: University of California Press.

Portes, A., and J. Böröcz. (1989) "Contemporary Immigration: Theoretical Perspectives on Its Determinants and Modes of Incorporation." International Migration Review 23(3):3606630 
Powell, W.W. and P.J. Dimaggio (eds) (1991) The New Institutionalism in Organizational Analysis. Chicago: The University of Chicago Press.

Ramakrishnan, K. and I. Bloemraad (2008) "Making Organizations Count: Immigrant Civic Engagement in California Cities" in Ramakrishnan, K. and I. Bloemraad (eds) (2008) Civic Hopes and Political Realities: Immigrants, Community Organizations, and Political Engagement. New York: Russell Sage Foundation.

Rana, J. (2011) Terrifying Muslims: Race and Labor in the South Asian Diaspora. Durham, NC: Duke University Press.

Schrover, M. (2006) " 'Whenever a Dozen Germans Meet ...' German Organisations in the Netherlands in the Nineteenth Century." Journal of Ethnic and Migration Studies 32(5):847-86.

Schrover, M., and F. Vermeulen. (2005) "Immigrant Organisations." Journal of Ethnic and Migration Studies 31(5):823-32.

Smith, M. P., and M. Bakker. (2008) Citizenship across Borders - The Political Transnationalism of El Migrante. Ithaca, NY: Cornell University Press.

Smith, R.C. (2006) Mexican New York, Transnational Lives of New Immigrants. Berkeley: University of California Press

Satzewich, V. (2007) "Multiculturalism, Transnationalism and the Hijacking of Canadian Foreign Policy: A Pseudo Problem?” International Journal 63(1): 43-67

Steuter, E., and D. Wills. (2009) "Discourses of Dehumanization: Enemy Construction and Canadian Media Complicity in the Framing of the War on Terror." Global Media Journal: Canadian Edition. Vol.2 (2)7:24

Tirman, John. (2004) The Maze of Fear: Security and Migration after 9/11. New York: The New Press

UNESCO. (2012) "Education in Pakistan - Fact Sheet." Education for All Global Monitoring Report October (www.efareport.unesco.org).

Vaughn, D. (2008). "Bourdieu and Organizations: the empirical challenge" Theory and Society 37(1):65-81.

Verba, S., L. Schlozman, K. and Brady, H.E. (1995) Voice and Equality: Civic Voluntarism in American Politics. Cambridge, MA: Harvard University Press.

Waters, M. and T. Jimenez. (2005) "Assessing Immigrant Assimilation: New Empirical and Theoretical Challenges.” Annual Review of Sociology 31:105-125

Wright, M., and I. Bloemraad. (2012) "Is There a Trade-off between Multiculturalism and SocioPolitical Integration? Policy Regimes and Immigrant Incorporation in Comparative Perspective." Perspectives on Politics 10(1):77-95.

Zolberg, A. R., and L. L Woon. (1999) "Why Islam is like Spanish: Cultural Incorporation in Europe and the United States." Politics and Society 27(1):5-38. 


\section{TABLES}

Table 1. Characteristics of Foreign-Born Pakistanis in the Greater Toronto Area and New York City.

\begin{tabular}{|c|c|c|c|c|}
\hline & \multicolumn{2}{|c|}{ Greater Toronto Area } & \multicolumn{2}{|c|}{ Metropolitan New York Area } \\
\hline & FB Pakistanis & $\begin{array}{c}\text { Canadian } \\
\text { Population }\end{array}$ & FB Pakistanis & US Population \\
\hline Total Population* & 97,070 & $2,576,025$ & 40,039 & $8,336,697$ \\
\hline Female $(\%)$ & 47.5 & 51.9 & 45.4 & 53.9 \\
\hline Less than High School (\%) & 14.1 & 19.7 & 15.4 & 20.0 \\
\hline High School Diploma (\%) & 23.3 & 25.5 & 25.8 & 26.5 \\
\hline College Degree or higher (\%) & 42.3 & 26.8 & 47.4 & 32.0 \\
\hline Labor Force Participation (\%) & 66.8 & 68.1 & 60.0 & 61.7 \\
\hline Unemployment rate & 4.39 & 4.51 & 8.62 & 8.03 \\
\hline $\begin{array}{l}\text { Median Total Income Per } \\
\text { Capita }\end{array}$ & 12,000 & 25,000 & 14,000 & 20,282 \\
\hline $\begin{array}{l}\text { Median Total Household } \\
\text { Income** }\end{array}$ & 50 to 54,000 & 75 to 79,999 & 68,035 & 68,625 \\
\hline $\begin{array}{l}\text { Low Income/Below } \\
\text { Poverty*** }\end{array}$ & 39.7 & 17.4 & 14.4 & 13.6 \\
\hline Median Household Size & 4.00 & 3.00 & 4.00 & 3.00 \\
\hline Homeownership & 62.0 & 73.6 & 61.9 & 54.7 \\
\hline Naturalized $\dagger$ & 60.8 & 74.4 & 67.0 & 47.4 \\
\hline $\begin{array}{l}\text { Proportion Arrived after } \\
2001+\dagger\end{array}$ & 26.8 & --- & 15.7 & --- \\
\hline $\begin{array}{l}\text { Source: } 2006 \text { Canadian Census and U. } \\
\text { Foreign-Born Pakistanis over the age } \\
\text { statistical area includes Northern New } \\
\text { *Total population estimates for Foreig } \\
2012 \text { American Community Survey. } \\
\text { **The } 2006 \text { Canadian Census only pro } \\
\text { ***The Canadian "low income" measu } \\
\text { measure indicates the proportion of ind } \\
\dagger \text { The proportion of naturalized citizen } \\
\uparrow \dagger \text { This measure represents the proport }\end{array}$ & $\begin{array}{l}\text { Aarch Current Popul } \\
5 \text { residing in the met } \\
\text { ey and Long Island } \\
\text { orn Pakistanis over } \\
\text { es ranges of househ } \\
\text { eports the proportio } \\
\text { duals with incomes } \\
\text { calculated among fc } \\
\text { of the foreign-born }\end{array}$ & $\begin{array}{l}\text { n Survey 3-year P } \\
\text { olitan statistical ar } \\
\text { age of } 15 \text { are taker } \\
\text { income. The 200-2 } \\
\text { individuals who } \\
\text { w the official pov } \\
\text { gn-born Pakistanis } \\
\text { istani population }\end{array}$ & $\begin{array}{l}\text { ed Cross-Section S } \\
\text { of Toronto and Ne } \\
\text { om the } 2011 \text { Canad } \\
3 \text { CPS provides spe } \\
\text {-identify as membe } \\
\text { line. } \\
d \text { the total foreign-b } \\
\text { arrived in Toronto }\end{array}$ & $\begin{array}{l}\text { le (2009-213). Data } \\
\text { ork City. The NYC } \\
\text { National Household } \\
\text { estimates of house } \\
\text { f a low-income fam } \\
\text { populations in Torc } \\
\text { NYC since the yea }\end{array}$ \\
\hline
\end{tabular}


TABLE 2. Programmatic Domain and Scope of Pakistani Non-Profit Organizations in Toronto and New York City Programmatic Domain Toronto New York

Geographic Scope

\begin{tabular}{rrrrrrrr}
\hline \multicolumn{2}{c}{ Local } & \multicolumn{2}{c}{ Transnational } & \multicolumn{2}{c}{ Local } & \multicolumn{2}{c}{ Transnational } \\
\hline $\mathrm{N}$ & $\%$ & $\mathrm{~N}$ & $\%$ & $\mathrm{~N}$ & $\%$ & $\mathrm{~N}$ & $\%$ \\
\hline 9 & 19.1 & 2 & 28.6 & 7 & 12.3 & 5 & 33.3 \\
11 & 23.4 & 2 & 28.6 & 7 & 12.3 & 3 & 20.0 \\
8 & 17.0 & 1 & 14.3 & 7 & 12.3 & 3 & 20.0 \\
9 & 19.1 & 2 & 28.6 & 5 & 8.8 & 2 & 13.3 \\
10 & 21.3 & 0 & 0.0 & 31 & 54.4 & 2 & 13.3 \\
\hline 47 & 100.0 & 7 & 100.0 & 57 & 100.0 & 15 & 100.0 \\
\hline 87.0 & & 13.0 & & 79.2 & & 20.8 & \\
\hline & 54 & & & & 71 & & \\
& .56 & & & & &
\end{tabular}

Social Services

Advocacy/Political

Economic

Cultural (non-religious)

Religious

Organizations per scope/city

Proportion per city (\%)

Total Organizations (N) Organization Rate ${ }^{*}$

Source: Database of Pakistani Non-Profit Organizations in London, Toronto and New York City (Chaudhary 2015b).

*The organization rate refers to organizations per 1000 immigrants in each city. 